https://helda.helsinki.fi

\title{
When the spirits arrived : Divergent Lakota Voices of the 1890 Ghost Dance
}

\section{Andersson, R.-H.}

2018

Andersson , R-H 2018 , ' When the spirits arrived : Divergent Lakota Voices of the 1890

Ghost Dance ' , Plains Anthropologist , vol. 63 , no. 246 , pp. 134-151 . https://doi.org/10.1080/00320447.2017.1338

http://hdl.handle.net/10138/309302

https://doi.org/10.1080/00320447.2017.1338426

cc_by_nc_nd

acceptedVersion

Downloaded from Helda, University of Helsinki institutional repository.

This is an electronic reprint of the original article.

This reprint may differ from the original in pagination and typographic detail.

Please cite the original version. 
"Our dance is a religious dance... we do not intend to stop dancing."

-Little Wound

"It is impossible for a dead man to come back alive again"

-Sitting Bull

"False prophets will spring up and they will show big sights and do great deeds, in that way the ones that will choose them will be deceived."

-Samuel White Bird

\section{The Study of the Lakota Ghost Dance}

The ghost dance was a distinguishing phenomenon in Lakota history that caused a lot of friction and divisiveness among the Lakota people in 1890. The three quotes above are examples of the various ways in which the Lakotas viewed the ghost dance. From the very beginning, however, the Lakota ghost dance was studied mainly from the perspectives of white Americans, and the Lakota views were incorporated into this narrative only in passing. The earliest accounts created a tradition of treating the Lakota ghost dance as a military, political, or religious-political movement. This approach is characterized by phrases such as "Sioux outbreak," "Messiah Craze," or "ghost dance war," so often used even in the titles of these works (e.g., Mooney 1991; Smith 1975; Utley 1963). The tradition continued into the late twentieth century, when alternative interpretations began to emerge (Andersson 2008a, 2008b; DeMallie 1982; Greene 2014; Ostler 2004; Warren 2015).

The ghost dance filled a religious void in the Lakota society resulting from years of oppression by the whites. Recent scholarship, such as Louis Warren, God's Red Son, Rani-Henrik Andersson's Lakota Ghost Dance of 1890 and Jeffrey Ostler's Plains Sioux and U.S. Colonialism have shown that the Lakotas did not use the ghost dance to start a final uprising against the white people. For the Lakotas, as well as for many other Indian tribes, the ghost dance was first and foremost an expression of religious beliefs. That it led to bloodshed is due to misunderstandings between the whites and the Lakotas on both individual and collective levels. The ghost dance caused tremendous frictions within the Lakota society, and the Lakotas found various ways to deal with the situation (Andersson 2003, 2008a; Greene 2014; Ostler 2004: 234-360; Utley 1963; Warren 2017).

However, there is still much to be understood about the ghost dance from the Lakota point of view. In this article, I present and analyze excerpts of some of the key documents representing different approaches to the ghost dance among the Lakotas. The documents give us new insights to the divergent Lakota approaches to the ghost dance. Some of the documents are long, 15 to 20 pages 
each; some are written in Lakota or Dakota and needed time-consuming translation. Some of the documents have been at least partly published before, while others have not. By presenting such differing, often opposing voices within the Lakota society, I hope to provide a fresh perspective on interpretations of the ghost dance.

In order to understand the ghost dance, one needs to understand the situation in which the Lakotas found themselves in 1890. Famine was a major concern in the spring of 1890 for the Lakotas living on the reservations of Pine Ridge, Rosebud, Cheyenne River, Standing Rock, Lower Brulé, and Crow Creek. As a compensation for the Sioux Act of 1889, which had divided the Great Sioux Reservation into six smaller reservations, the Lakotas had been promised additional rations, including beef ( 51 Cong. Rec, 2682 (1890): 23-32; Greene 1970: 41-72; Hoover 1989: 57-75; Ostler 2004: 217-239). However, the amount of beef was gradually reduced, causing great anxiety and hardship among the Lakotas, as can be seen in the following statements by chiefs Little Wound and Man Afraid of His Horses. The statements were made to Hugh D. Gallagher, the Indian Agent on the Pine Ridge Reservation, in July 1890. They wanted to inform President Benjamin Harrison, the Great Father, of their dire situation.

Little Wound: Some years ago we were like drunken or crazy people. We were fighting and killing not only the whites but our own people. We were induced to give up that kind of life upon promises made us by the Great Father through the representatives he sent among us to make a treaty of peace. Had we known then how the Government intended to treat us we would never have signed this treaty. Look at these people around you, see their sunken cheeks and emaciated bodies. Many of these, you will notice, have drooping heads and an expression of unconcern in their faces that shows plainly the ravages that hunger has reduced them to the verge of idiocy. This has been a hard winter upon us. Many of our children died from hunger. Surely the Great Father did not know this or he would not have taken away a million pounds of our beef. Great Father you promised us plenty to eat. ... We would like for you to give us back the beef you took from us last winter. We fear another winter like the past would render our people desperate causing trouble that would give us a bad name (Little Wound in Hugh D. Gallagher to the Commissioner of Indian Affairs [CIA], July 23, 1890, Letters Sent to the Office of Indian Affairs by the Agents or Superintendents at the Pine Ridge Agency [LSASPR], National Archives and Records Service, Washington, DC [NARA], Record Group [RG] 75, Records of the Bureau of Indian Affairs [RBIA], M 1282, Vol. IX, Roll 10: 335).

Man Afraid of His Horses: There was a time when we did not have to assume the character of beggars. ... Then we were free to go where we pleased while now we are penned up like so many cattle. . . There was a time when the 
buffalo covered our plains and furnished us with all the meat we needed. . . . Beef is everything to an Indian, you might take away all else his complaint would not be so great as if his beef was taken from him. We do not blame you for this condition of things (Young Man Afraid of His Horse in Gallagher to CIA, July 23, 1890, LSASPR, NARA, RG 75, RGBIA, M 1282, Vol. IX, Roll 1: 336-337).

Both chiefs expressed their concern about the shrunken beef rations now that the buffalo were gone. The chiefs politely expressed that they could not understand why this situation had been forced upon them. Little Wound feared that trouble might be ahead if starvation continued. The news of the ghost dance, or spirit dance (wanáği wačhípi kin), ${ }^{2}$ and its promise of the return of the buffalo arrived in the middle of this destitution, causing great excitement among the Lakotas.

\section{The Flowering Tree and the Nations Hoop: True Believers}

In 1889, the Lakotas decided to send a delegation to Nevada to meet with the Messiah of the new religion, a Paiute Indian called Wovoka (Hittman 1997; Warren 2015). After returning home in the spring of 1890 they gave their people several accounts of their experiences in Nevada and brought new hope to the suffering Lakotas (Andersson 2008a: 31-48; Mooney 1991: 816-824). Short Bull, one of the leaders of the Lakota ghost dance, relates his meeting with Wovoka: ${ }^{3}$

And one of the Paiutes sat down in the middle where we were sitting and shouted something. After a while a white man [Wovoka wearing white man's clothing] came and stood in the middle of them, but not one of us looked steadily at him. He stood with his head bowed and all at once, surprisingly, he made a speech in the Lakota language. He said as follows: "My pitiful children," meaning these [the gathered Indians], "because you come to me suffering you will hear those things that are right and you will act accordingly," he said. "By means of a dance you will see again those of your relatives who died long ago; but only if you do it properly will you truly see your people. And because father told me these things, remember me! Behold me, my sons, I myself was killed long ago by the white men, and therefore now there are many holes in me [reference to the suffering of the Christ on the cross]. They went away, and now they honor me," he said, "but because you Indian people are suffering I am paying you this visit so in the future you and your relatives who have died will see one another. From this time on, by dancing and [doing] those things that I will say, you will live well. My

\footnotetext{
${ }^{2}$ A better translation for the ghost dance would be spirit dance. The Lakota word wanáğ $i$ refers to the spirits of the departed and the name for the ghost dance in Lakota is wanáği wačhípi kị, the spirit dance. See Andersson 2008a: 29, 46-54.

${ }^{3}$ This text has been translated into English by Raymond J. DeMallie, Dennis M. Christafferson, and Rani-Henrik Andersson, American Indian Studies Research Institute, Indiana University, Bloomington Indiana, spring 2005, from Father Buechel's original Lakota manuscript. In translating this text we tried to maintain as much of the Lakota style of speech as possible. The English version is, therefore, somewhat repetitive, but at the same time it gives a wonderful insight into Short Bull's experiences. Short Bull gave several accounts of the journey.
} 
beloved sons, do not murder one another! Whoever commits murder does evil. And love one another! And take pity on one another! If you act in this manner I will give you more concerning the ceremony. And those people should take sweat baths. While you are dancing you must not eat any at all of the white man's food! And fast! And you must not wear any metal. And while you dance you must dance with your eyes closed. If you think about one of your relatives who died long ago you will see him. Well, it is not possible for you Indians and the whites to become the same as long as your generations continue. Therefore my father made you of a different nature and also gave you a country. And he will see any bad things that you do, so from this time on whatever you do, I will watch over and keep. The Indians are far below because my father made you last. Now I will help you and you will live well. In the future these things will be fulfilled. ... This will not be for long. Well, I give you these things, so remember them well!" (Short Bull in Eugene Buechel Manuscript Collection [EBMC], Holy Rosary Mission, Special Collections and Archives [HRMSC]. Marquette University Libraries, Milwaukee, Wisconsin 1-2).

Kicking Bear, another ghost dance leader, described his experience when meeting Wovoka:

Then from an opening in the sky we were shown all the countries of the earth and the camping-grounds of our fathers since the beginning; all were there, the tepees, and the ghosts [spirits] of our fathers, and great herds of buffalo, and a country that smiled because it was rich and the white man was not there (Kicking Bear in James McLaughlin to CIA , October 17, 1890, Special Case No. 188-The Ghost Dance, 1890-1898 (SC 188), NARA, RG 75 RBIA, M 4728-4729, Reel 1-2: 31-33. See also Annual Report of the Commissioner of Indian Affairs [ARCIA] 1891: 126-127 and Mclaughlin 1989: 185-189).

Kicking Bear continued with a description of the Christian aspects of the ghost dance. According to Kicking Bear, Wovoka showed his hands and feet, which had wounds made by the whites when they crucified him. He was going to return on the earth, and this time he would remain and live with the Indians, who were his chosen people. Kicking Bear promised that there was no need to be afraid of dying, or fear the US army. He said: ". . . if a red man die at the hands of the whites while he is dancing, his spirit will only go to the end of the earth and there join the ghosts of his fathers and return to his friends next spring" (Kicking Bear in James McLaughlin to CIA, October 17, 1890, SC 188: 31-33).

Back on Pine Ridge, several dance camps were established, and the ceremonies were led by, among others, Short Bull and Kicking Bear. During a dance ceremony on Pine Ridge, Pretty Eagle experienced a vision and learned a new song that he taught to his people:

And then, again when we danced, I was overcome and then again I became unconscious. And once again, when I came to my senses, then I realized that I stood on a hill with a man. Then he said this: "My son, I will give you this 
song so therefore, I called you quickly," he said. And then as I stood there, I heard this song:

My Father said this, so sing it/Those things that grow on the earth are mine/Those things that grow on the earth are mine/ Father said this, so sing it, so sing it/ Father said this, so sing it, so sing it.

And then I turned back there and then again I woke up in the middle of the dance circle. So again those who fainted told about it, so there I joined in, and I brought back that song and so I told about it and sang it. And so it was, and many were overcome and fainted (Pretty Eagle in EBMC, HRMSCA: 1-6).

Like many other ghost dancers, Pretty Eagle fell in a trance during the ceremony and had a vision that took him right back to the time when buffalo was plentiful. He was overcome with emotion:

... I danced the dance with my eyes closed and it seemed like [I heard] those sounds of buffalo hoofs galloping and then little by little the sound of bird wings were mixed together and it seemed that the buffalo really bellowed and grunted, and it was like a buzzing noise and the dance songs disappeared and were soon gone. ... And I looked quickly, but thus they were dancing and they were only ordinary people and my heart was beating fast and I was shaking . . . So I know this about these things, and now I do this for him [perhaps a reference to Wovoka]. Little by little as I danced my eyes shut, I knew nothing, although I believed it then (Pretty Eagle in EBMC, HRMSCA: $1-6)$.

Later, on October 30, 1890, Short Bull spoke to the gathered people, promising to hasten the coming of the new world. In his speech, Short Bull evokes images of Lakota traditions. The sprouting tree symbolizes the prosperity of the Lakota people and a renewal of their traditional culture. By promising to bring about the new "Indian Paradise" after dancing "the balance of this moon," Short Bull tried to keep his followers united despite the growing threat of military intervention. They no longer needed to wait until the spring of 1891 for the coming of the new world. He assured that there was nothing to be afraid of, since the Indians were living a sacred life:

Now there will be a tree sprout up, and there all the members of our religion and the tribe must gather together. That will be the place where we will see our dead relations. But before this time we must dance the balance of this moon, at the end of which time the earth will shiver very hard. Whenever this thing occurs, I will start the wind to blow. We are the ones who will then see our fathers, mothers, and everybody. We, the tribe of Indians, are the ones who are living a sacred life. God, our father himself, has told and commanded and shown me to do these things [the ghost dance] ... Now, we must gather at Pass Creek where the tree is sprouting. There we will go among our dead relations. You must not take any earthly things with you. You must not be afraid of anything. The guns are the only things we are afraid of, but they 
belong to our father in heaven. He will see that they do no harm. Whatever white men may tell you, do not listen to them, my relations (Short Bull in the Annual Report of the Secretary of War [ARSOW] 1892: 142-143).

By October the situation had escalated. Many Indian agents asked for military protection, and the newspapers were calling the Indian dance a war dance. From the agents' point of view, dancing Indians were beyond their control, which meant that they had failed in their duties to keep the Indians quiet on their reservations. The ghost dance had to be stopped. The newspapers, on the other hand, needed great stories to report. Rumors started to circulate, and by late November US army troops arrived on Lakota reservations. The ghost dancers, who continued to dance despite calls to stop, began to fear for their lives (Andersson 2008a; Greene 2014; Ostler 2004: 264-360). On October 30, Short Bull gave them what they wanted, the promise of a safe place in a new Indian country where no white man could disturb them.

Bulletproof ghost dance shirts were another feature of the Lakota ghost dance that emerged from the feeling of despair during this time. As the fear of military intervention grew, Lakotas started to believe that the shirts were "impervious to missiles" as Short Bull put it (Short Bull in Walker 1991: 143). Both Short Bull and Kicking Bear refer to the invulnerability of the dancers, which might be a reference to the bulletproof shirt. White observers and historians alike interpreted this to be a sign of Lakotas preparing for war (Andersson 2008a: 67-73).

To understand the significance of these accounts, one needs to place them not only in the context of reservation life but also in the framework of Lakota history, culture, and religious traditions. Such experiences as meeting spirits in the spirit world were natural in Lakota culture. Things that were revealed in visions were as real as those in the tangible world. The return of the buffalo is also a common theme in Lakota culture. In the Lakota creation myth, the Lakotas and the buffalos once emerged together from a cave in the Black Hills. By 1890 the buffalo was gone, but the ghost dance promised to bring it back. The ghost dance, like the traditional Sun Dance, was a ceremony of renewal. The dance circle itself represented the čhaygléška waǩ̆áy, the nation's hoop or the unbroken unity of the Lakota people. The infamous ghost dance shirt, which the Lakotas called a sacred shirt, oglé wakháy kiך, had its roots in Lakota traditions as well. Shields and other sacred objects, including paintings, could be considered bulletproof. They were signs of the holder's medicine or power. The ghost dance shirts served a similar function: as symbols of sacred powers, they helped the ghost dancers to stay united. These examples show that the stories were not strange or weird to the Lakotas as they were to most white observers at the time. Simply, as Pretty Eagle said: "I believed it then." (Pretty Eagle in EBMC, HRMSCA: 1-6). 
Still, it needs to be understood that not all Lakotas, not even all ghost dancers, believed in the protective qualities of the ghost dance shirts. Oglala chief Big Road, for example, commented on the shirts saying: "We never prayed for anything but happiness. We did not pray that white people should all be killed. The shirts we wore were made for us to go to heaven (...) I never believed that bullets could not go through the shirts. Some foolish people might, for there are foolish Indians just as there are foolish white people, but I never heard any Indian in the dance ever say he thought the shirt would protect him. (Big Road in Washington Evening Star[WES], January 28, 1891. See Warren 2015: 162).

One of the best-known ghost dance accounts comes from the medicine man Black Elk, who said that in a vision during a ghost dance ceremony he could see the "flowering tree" and he "thought that if this world would do as the vision teaches, the tree would bloom here too." For him, like for Short Bull, the flowering tree represented the Lakota people. In "this world" the Lakotas were suffering and the tree was not blooming, but the sacred tree of the vision was flowering again. He believed that the ghost dance was the answer to his prayers and would make the Lakota nation flourish again (Black Elk in Neihardt 2008, orig. 1932: 194-199; Black Elk in DeMallie 1986: 259-26).

Such documents represent the voices of those who became ardent believers in the ghost dance and clearly connected it with old Lakota traditions. However, among those who could be regarded as active ghost dancers or true believers were also many Christian Lakotas. It has to be understood that the Lakota concept of religion did not necessarily require a person to discard his/her old religious beliefs at, for example, accepting Christianity. The Christian God was absorbed as a part of the wakháy, sacred, beings. The ghost dance thus gave means to combine Christian beliefs and old Lakota traditions (Andersson, 2008a: 48-73; DeMallie 1982: 385-405; for Lakota religion, see DeMallie and Parks 1987; Walker 1991). The following account by Little Horse, a Christian ghost dancer shows how Christian teachings merged into the ghost dance:

Two holy eagles transported me to the happy hunting grounds. They showed me the Great Messiah there, and as I looked upon his fair countenance, I wept, for there were nail-prints in his hands and feet, where the cruel white men had fastened him to a large cross. There was a small wound in his side also, but as he kept his side covered with a beautiful blanket of feathers. (...) $\mathrm{He}$ insisted that we continue the dance and promised me that no whites should enter his city nor partake of the good things he had prepared for the Indians. The earth, he said, was now worn out and it should be repeopled. He had a beard and a long hair and was the most handsome man that I ever looked upon (Little Horse in Illustrated American [IA], January 17, 1891, 332. See Boyd 1891: 193-194).

It is safe to argue that there were both non-progressive traditionalist Lakotas and progressive Christian Lakotas who embraced the teachings of the ghost dance. This also shows that it is far too simplistic 
of an analysis to claim that the ghost dance affected only non-progressive Lakotas, who tried to use it for political or military purposes. The religious message of the ghost dance was understandable and appealing across the artificial progressive-non-progressive line (see Andersson 2008a; Warren 2015).

\section{“I Don't Want My People to Fight:" Caught In-Between}

The ghost dance entailed difficult decisions for many Lakotas. Many wanted to see the dance ceremony and to receive a message from the spirit world that would confirm that the religion was true. Two of the most famous of those caught in-between were the Hunkpapa chief and medicine man Sitting Bull and the Oglala chief Red Cloud. Many whites accused them of being leaders of the ghost dance and instigators of trouble.

Red Cloud did not participate in the dance, but he allowed his people to dance if they wished, and his son Jack Red Cloud was an active dancer. While some scholars have seen this as evidence of his sympathy toward the ghost dance, one needs to realize that in Lakota culture each individual could decide for himself. The chiefs had no coercive power to make someone obey. This is even truer in the realm of religion. As the anthropologist Raymond J. DeMallie has noted, there was no single body of doctrine or official religion, but every individual interpreted and made changes to the general belief system according to their own experiences (DeMallie 1987: 34). Red Cloud could not prevent his people from dancing. We do not know whether he wanted to do so, but his approval does not make him a ghost dancer or an instigator of trouble. In an interview to Harper's Weekly magazine he noted that if the religion were true it would "spread all over the world" and if false "it would melt like snow under the hot sun" (Red Cloud in the Harper's Weekly Magazine [HWM], (34) 1890: 944). In November 1890, when the US Army was sent to suppress the ghost dance, Red Cloud sent a letter to his friend, Thomas A. Bland of the National Indian Defense Association saying that he did not want to fight and his people did not want to fight, indeed they could not even if they wanted to. Red Cloud explained: "We have lots of old women and we have lots of old men. We've got no guns and we can't fight, for we have nothing to eat, and are too poor to do anything" (Red Cloud to Thomas A. Bland, December 10, 1890 in Bland 1891: 19-21. Also in Cong. Rec., 51st Cong. 1st Sess., Vol. 21, Part 14, December 19, 1890: 702-703). His letter continued with a long description of the difficulties the Lakotas on Pine Ridge were facing, pointing out that more than 200 people had died of hunger and disease during the past year. He also strongly denied any connection to the ghost dance:

... I haven't been to see the dancing. I will try to stop it. Those Indians are fools. The winter weather will stop it, I think. Anyway, it will be over by spring. I don't think there will be any trouble. They say that I have been in the dance. That is not right. I have never seen it (Red Cloud to T. A. Bland, 
December 10, 1890, in Bland 1891; 19-20. Also in Cong. Rec., 51st Cong.

1st Sess., Vol. 21, Part 14, December 19, 1890: 702-703).

For Red Cloud and many others the decision not to become an active ghost dancer had more to do with politics than religion. Perhaps Red Cloud did not believe in the ghost dance, but he also knew the power of the United States all too well. He understood that ghost dancing might lead to trouble and as a leader he could not let that happen. In early December, he sent a large delegation to the ghost dancers' camp to try to convince them to give it up to avoid further trouble. Red Cloud was, indeed, caught in-between the ghost dancing and non-ghost dancing Lakota factions.

On October 9, 1890, the ghost dances had begun on the Standing Rock Reservation, in Sitting Bull's camp. He had been one of the Lakota leaders behind the defeat of Colonel George Armstrong Custer's $7^{\text {th }}$ cavalry at Little Bighorn in 1876 , and he was also the last Lakota leader to surrender in 1881. This made him one of the best-known — and perhaps the most feared — of the Lakota leaders. He was accused of using the ghost dance to plan a major uprising for the spring of 1891. Among his accusers were Standing Rock Reservation Agent James McLaughlin and Major General Nelson A. Miles, who both had personal issues with Sitting Bull (see Utley 1993; Vestal 1989, orig. 1932). His accusers also included fellow Lakotas, most of them members of reservation Indian police, whose opposition stemmed from old feuds. These personal relations and animosities were behind the attempted arrest that resulted in Sitting Bull's death on December 15, 1890. Sitting Bull has not left many documents that would describe his sentiments about the ghost dance. Most Indian accounts agree that he wanted to dance and receive a vision that would have confirmed the truthfulness of the religion, but he never received such a message from the spirits. Therefore, he was not a ghost dance believer, but, much like Red Cloud, allowed his people to dance. Sitting Bull made his own position clear when he stated that it is "impossible for dead man to come back alive." (Sitting Bull in Old Bull, Walter S. Campbell Manuscript Collection [WSCC], University of Oklahoma Libraries and Archives, Norman, Oklahoma [UOLA], Box 105, Folder 11: 32). But he also insisted that "our own religion is best for us" (Sitting Bull in Mary C. Collins, Walter Mason Camp Manuscript Collection [WMCC], Indiana University, Lilly Library [IULL], Bloomington, Indiana, Box 6, Folder 3, Envelope 78).

Still, Sitting Bull wanted to learn more about the ghost dance. During a meeting at his camp in November 18, he asked Agent McLaughlin for permission to go west to learn about the new religion: "Father, I will make you a proposition which will settle this question. You go with me to the agencies to the west, and let me seek for the men who saw the messiah; and when we find them, I will demand that they show him to us and if they cannot do so I will return and tell my people it is a lie." (Sitting Bull in McLaughlin to CIA ,November 19, 1890, ARCIA: 330-331. See also Utley 1993: 288289).The Agent refused the request. Perhaps the lengthiest document of Sitting Bull's views is a letter 
to Agent McLaughlin. Sitting Bull dictated the letter to his son-in-law Andrew Fox a few days after the agent's visit, explaining his views on the situation and why he needed to learn the truth behind the ghost dance. He told the Agent that he had been invited to go to Pine Ridge, where he could learn more about the religion:

God made you - made all the white race and also made the red race - and gave them both might and hear [sic] to know everything in the world, but gave the whites the advantage over the Indians. But today God, our father, is helping us Indians. So all we Indians believe. Therefore I think this way: I wish no man to come to me in my prayers with gun or knife. Therefore all the Indians pray to God for life, and try to find a good road, and know nothing wrong in their life. This is what we want, and to pray to God. But you did not believe us. You should say nothing against our religion, for we said nothing against yours. You pray to God. So do all of us Indians, as well as the whites. We both pray to only one God, who made us all. Yet you, my friend, today you think I am a fool, and you gather up some of the wise men among my people on your side, and you let the white people back East know what you think. I know that, but I do not object; I overlook that, because I am foolish enough to pray to God. Therefore, my friend, you don't like me. Well, my friend, I don't like it myself when someone is foolish. . . . You don't like me because you think I am a fool, and you imagine that, if I were not here, all the Indians would become civilized, and that, because I am here, all the Indians are fools. I know this is what you publish in the newspapers back East. I see it all in the paper, but I overlook that. When you were here in my camp, you gave me good words about my prayers, but today you take it all back again. And there is something else I want you to know. I am obliged to go to Pine Ridge Agency and investigate this ghost dance religion (Sitting Bull to Andrew Fox, November 1890, WSCC, Box 114, Folder 6. See also Vestal, 1989: 283-284).

Sitting Bull emphasized the importance of religion to whites and Indians alike and emphasized the Lakota right to worship in their own way. He also pointed to the fact that the Agent did not like him and considered him to be foolish and opposed to all civilization efforts. The fact that he said he needed to go to Pine Ridge most likely made Agent McLaughlin more determined to arrest Sitting Bull as soon as possible. Like Red Cloud, Sitting Bull was cast as a troublemaker, and even the US Congress expressed a belief that he was planning an outbreak (see, Congressional Discussion, Cong. Rec., 51st Cong. 1st Sess., Vol. 21, Part 14, December 3-4, 1890: 46-47, 69-70; December 19, 1890: 702-703). While these two leaders are perfect examples of the Lakotas' difficult situation in the fall of 1890, many other ordinary Lakotas found themselves caught in-between the ghost dancers and non-ghost dancers as explained by Brulé Ring Thunder in a letter to former agent Lebbeus F. Spencer in December 1890:

My dear friend. - It made my heart very good to get your letter and that you remembered me. It made me glad that you thought I had not gone with the 
wild Indians. The agent sent me over to Black Pipe three times to counsel with the dancers, but they had no ears, called me a fool, and would not listen. I did all I could to keep my people from joining the ghost dancers, but some of them would not listen to me, and went off to Pine Ridge. I expect to stay in my camp, with my people, and if the Dakotas fight, they fight. My heart is not with them. The ghost dancers told me if I would join them, I would never have any more pain or sorrow, but if I followed after the ways of the white man, my path would be hard and full of trouble. I told them a long time ago, I was one of their bravest warriors, but now that time is past. I have no more desire to fight. The ways of the white man seem hard at times, but if they will give us back our beef and rations, all will be well with us. I shake your hand with my heart (Ring Thunder to L. F. Spencer, December 5, 1890, Lebbeus Foster Spencer Papers, (LFSP), History Colorado [HC] StephenH. Hart Library and Research Center [SHHLR], MSS 596).

Ring Thunder, like many others, tried to act as a mediator between the ghost dancers and the officials, but was met with contempt. He also expressed concern that ghost dancing might lead to fighting. He was not alone in this belief. As early as June 1890 Crow (Kangi), a Brulé from Rosebud, wrote to an Iowa settler G. C. Douglas about possible trouble ahead. His long letter included a warning: "tell your people that they will fight with the whites, it is said" (Kangi to G. C. Douglas forwarded to Sect. Interior, June 13, 1890, NARA, RG 75.4, RBIA Letter 18612). ${ }^{4}$ Crow does not clearly say that the ghost dance is the cause of trouble, but the letter was forwarded to the Secretary of the Interior where it alarmed already nervous officials about possible trouble brewing on Lakota reservations. Perhaps the earliest warning that reached the officials was written in May 1890 by a settler in South Dakota, Charles L. Hyde, to the Secretary of the Interior. He believed that some of the Lakotas were planning an outbreak. His informant was a mixed-blood student at a Presbyterian College in Pierre South Dakota (Charles L. Hyde to Sect. Interior, May 29, 1890, NARA, RG 75, RBIA SC 188, Box 199). Crow's warning reinforced the already circulating rumors of a possible outbreak.

\section{“Messiya Itonsni:" The Lie of the Messiah}

Less than a third of all Lakotas actively participated in the ghost dance. This amounts to approximately 4,000 ghost dancers. Yet it is very difficult to estimate who was a dancer or a true believer and who was not. Was a person who witnessed a ceremony once or twice an active ghost dancer (see Andersson 2008a: 76-78)? As only 28 percent of the Lakotas participated in the dances, there had to be a great number of those who did not and who opposed it. One interesting group of ghost dance opponents were those who had entirely abandoned their traditional belief system and had

\footnotetext{
${ }^{4}$ Translated from Lakota by Rani-Henrik Andersson, August 2015.
} 
become devout Christians. They denied the ghost dance for religious reasons. The following is an illustrative comment by Samuel White Bird of the Lower Brulé Agency. In an article in the Iapi Oaye entitled "Messiya Itonsni," the "Lie of the Messiah," he writes about false prophets and the danger of believing in them. He says:

People went and took part in a prayer [ghost dance] and then a man told them about spirits. And then they considered it to be true and really worshipped. And then I took the Bible and read it, and then my heart was sad. (...) My friends I want you to be clear-minded. Many take part in the prayers and they say that they believe in the spirit words, it is said. But the sacred book also said this!: Messiah lies and false prophets will spring up and they will show big sights and do great deeds, in that way the ones that will choose them will be deceived. This is what it means and therefore I wish to say that the Bible speaks the truth, so it is that they believe in something, but it is so that this one is indeed bad, so the Bible tells us. My relatives, I myself joined the prayers [The Christian church] and then I believe in the sacred words, and I [also] did wrong regularly, but Jesus came on top of the world so that we would live (Sam White Bird in Iapi Oaye [IO], November 1890: 38) ${ }^{5}$

Similar thoughts about the danger of believing in false prophets was expressed by a Christian Lakota girl who had attended St. John's school at the Episcopal Mission on the Cheyenne River Reservation.

In a letter to Bishop William H. Hare she wrote:

I think you have heard of very strange stories of what is going on in Dakota at this time. But, dear Bishop, do not worry about us, for we are trying very hard not to be led away to believe in false ones. When I hear an Indian talk of this strange story, I tell them of the Saviour who came to save all the world. I was thankful that my father put me in school and I have been told of the true Christ (Anonymous Lakota girl in a Letter to Bishop William H. Hare in WSCC, UOLA, Box 110, Folder 2, Originally published in the Sioux Falls Press, December 16, 1890).

Another girl, still attending St. John's, stressed that most Christian Indians remained true to Christ and feared that ghost dancing might cause trouble:

I suppose you have heard about the Indians having 'Ghost Dances'? I think none of the Church Indians have anything to do with the matter, but the Indians that live on Cherry Creek don't know any better, and are very wild. I hope they won't go too far or make any trouble (Anonymous Lakota girl in a Letter to Bishop William H. Hare in WSCC, UOLA, Box 110, Folder 2, Originally published in the Sioux Falls Press, December 16, 1890).

\footnotetext{
${ }^{5}$ The text was translated by Rani-Henrik Andersson, December, 2013.
} 
Yet another group, including many of the Indian policemen, opposed the ghost dance for political reasons. While they saw the religious potential of the ghost dance, many Indian policemen decided to stay in their jobs. Eagle Boy, a Hunkpapa policeman, went to see a dance ceremony in Sitting Bull's camp, because he wanted to see his dead grandmother, but he was not able to receive a vision, so he "lost faith in it" (Eagle Boy in WSCC, UOLA, Box 106, Folder 54: 23). Even Agent James McLaughlin noted that the ghost dance affected several of his policemen, but they still worked with the Indian agents in suppressing the dances (McLaughlin 1989: 191; Utley 1993: 284-285). Only a few policemen decided to become active ghost dancers. Perhaps the most famous of these was the Minneconjou chief Hump, who was a policeman on the Cheyenne River reservation, but then became an active ghost dancer. Later he decided to join the US army as a scout in helping to quiet the unrest caused by the developments in December 1890 (Andersson 2008a: 21, 46, 79, 87-88, 134, 146).

Internal divisions and different political views, then, determined how Lakotas approached the ghost dance. These internal divisions and political views become apparent in a letter written by Oglala chief American Horse. In December 1890 he wrote to his friend James Landy in Cincinnati describing the volatile situation on Pine Ridge:

I am very much pleased with your advice in regard to the situation at this agency, and I shall follow it out as far as I am able to exert any influence. I have been following it with the idea to lead my people toward civilization, which has made me many enemies, yet I have not been discouraged, although at times the position is a very unpleasant one, among the Indians. The ghostdancers, those who believe in the coming of the new Messiah, and who came from Rosebud Agency to this reservation have destroyed all the properties of my people and appropriated what they did not destroy, even knocked the doors and windows in, so that we are left homeless. These things were done while the agent ordered the Pine Ridge Agency Indians to come in to the Agency while the troops are here. I am sorry for those Indians who are crazed with this false idea (American Horse to J. Landy, December 1, 1890, American Horse Papers (AHP), Yale University Yale Collection of Western Americana [YUYCWA], Beinecke Rare Book and Manuscript Library [BRBML], MSS S 903).

American Horse had befriended James Landy and his family in the 1880s. He had received a picture of himself with the Landy family, which was hanging on his wall at the time of the ghost dance. In his letter American Horse described how ghost dancers had entered his home and shot bullets through the heart and forehead of the picture. The ghost dancers had taken everything from his home, including his horses, and killed his cattle. American Horse's experience is a poignant example of the deep divisions on Pine Ridge and demonstrates how the ghost dance brought these tensions to the foreground. American Horse lamented: "If these Indians should kill me remember I shall die for a good cause. I am trying to advance these Indians, but instead they are growing worse and some of 
them hate me so that they say they would shoot me, if they should have an opportunity" (American Horse to J. Landy, December 1, 1890, AHP, YUYCWA, BRBML MSS S 903. See also Gage 2015: 72-73).

Another illustrative case is Sitting Bull's brother-in-law Grey Eagle. He had been friends with Sitting Bull for years, but had decided to take up the "white man's road," which caused friction between them. In December 1890 he was a member of the reservation Indian police. He visited Sitting Bull and tried to convince him to obey the rules and stop the ghost dances on Standing Rock (Utley 1993: 211-212, 271; Vestal 1989: 210-213, 263, 296-298). The following discussion between the two illustrates their differing political views on the situation. Grey Eagle relates this discussion as follows:

Grey Eagle: Brother-In-Law, we've settled on reservation and we're under [the] jurisdiction of [the] government. We must do as they say-we must cut out the roaming around. Live as they say and must cut out this dancing.

Sitting Bull: Yes you are right, but I could not give up my race as it is seated in us. You go ahead and follow what white man says, but for my part, leave me alone.

Grey Eagle: If you're not going to obey and do as the whites say, you are going to cause a lot of trouble and [it will] cost your life. I have sweared [sworn] to stay by [the] government and we have been friend[s] a long time, but if you are not going to do as white [men] say, we will not be together any more (Grey Eagle in WSCC, UOLA, Box 106, Folder 54: 50-53).

The discussion makes clear the political division on Standing Rock. For Grey Eagle, ghost dancing signified Sitting Bull's reluctance to accept the prevalent situation and realities of reservation life. Sitting Bull clearly understood the risks, but wanted to continue on the chosen path. The ghost dance was one more divisive issue that in Grey Eagle's mind had the potential to cause trouble. This was why many Lakotas did not join the ghost dancers. They believed that following the reservation rules was a better way to continue with their lives. The ghost dance was causing problems by breaking these rules; it was dangerous.

\section{“Our Dance Is a Religious Dance"}

After the US army entered the Lakota reservations on November 19, 1890, tensions started to mount. Misunderstandings gave rise to rumors of wild Indians dancing a war dance. As the threat of military intervention seemed obvious, some Lakotas started to arm themselves, preparing for a confrontation. This, however, does not mean that the ghost dance became a warlike demonstration as most contemporary whites and historians believed. Little Wound's words are quite revealing: 
What have they [the soldiers] come for? We have done nothing. Our dance is a religious dance and we are going to dance until spring. If we find then that the Christ does not appear we will stop dancing; but, in the meantime, troops or no troops, we shall start our dance on this creek [Medicine Root] in the morning. I have also understood that I was not to be recognized as a chief any longer. All that I have to say to that is neither you nor the white people made me a chief and you can throw me away as you please, but let me tell you . . . that the Indians made me a chief, and by them I shall be so recognized so long as I live. . . . We do not intend to stop dancing (Little Wound in John M. Sweeney to Agent R. F. Royer, November 22, 1890, The Edward E. Ayer Collection (EAYC), The Newberry Library [NL], Chicago, Illinois, MS 3176; New York Times [NYT] November 23, 1890: 5; Chicago Tribune [CT], November 23, 1890: 1; Omaha Daily Bee [ODB], November 23, 1890: 1).

Chief Big Road echoed Little Wound in a statement he made in January 1891 for the Washington Evening Star newspaper. Big Road tried to explain that many Lakotas belonged to Christian churches and the ghost dance was nothing more than a religious ceremony:

This dance was like religion; it was religion. Those who brought the dance here from the west said that to dance was the same as going to church. White people pray because they want to go to heaven. Indians want to go to heaven, too, so they prayed, and they also prayed for food enough to keep them out of heaven until it was time to go. Heaven must be a nice place or the white men would not want to go there. That was why the Indians would like to go. We danced and prayed that we might live forever; that everything we planted might grow up to give us plenty and happiness. Here was no harm in the dance. The Messiah told us to send our children to school, to work on our farms all the time and to do the best we could. He also told us not to drop our church. We and our children could dance and go to church, too; that would be like going to two churches. I never heard that the Messiah had promised that the Indians should be supreme or that the white men should be destroyed. We never prayed for anything but happiness. We did not pray that white people should all be killed (Big Road in WES, January 28, 1891. See Warren 2015: 162; Warren 2017).

The dancing Lakotas were clearly beyond the agents' control and were defying authority, but was a military solution the only way to deal with the situation? Probably not, but as matters went from bad to worse, Sitting Bull was killed on December 15, and 250 Lakotas were killed at Wounded Knee Creek on December 29, 1890.

Perhaps in an attempt to justify his participation in the ghost dance, chief Big Road stated the following after the tragedy at Wounded Knee:

When I promise something I do it, when the great Father promises he never does it. Yet they say the Indian is a bad man. The great Father should have good agents, and he should not lie to us. ... They promise us good thingsmoney, clothes, tools, and plenty of food for our good lands, and they said 
they would teach us to farm, but they lied. I do not lie like the white men. . . . The Indians should stand up for their rights. They have a right to food and money, and clothing, and everything that was promised them [in the Act of 1889]. The Indian[s] have not stolen from the white neighbors, but they have stolen our cattle and horses. The Indians have not killed our white neighbors, but they have killed our women and children. We did not want to fight. The Indian who is starving has a right to complain, has a right to dance the same way as a white man. Let the great Father do right by us and there will be no trouble. Our hearts are not bad, but we have some rights (Big Road in Colby 1892: 190).

While this might be a somewhat defensive account, it is most likely an accurate statement of the Lakotas' feelings during and after the ghost dance troubles. It all went back to the injustices, cut rations, and famine forced upon the Lakota people. As early as July 1890, Little Wound had noted: "We fear another winter like the past would render our people desperate causing trouble that would give us a bad name." Little Wound's prediction turned out to be true. (For similar statements see Rocky Bear, Two Strike, Crow Dog and American Horse in Colby 1892:185-189; Statement of American Horse in 51st Cong., 1st Sess., House of Representatives Committee on Indian Affairs, Council Held with a Delegation of Sioux Indians, Unpublished Hearing, April 15, 1890, Indiana University, Main Library [IUML], Bloomington, Indiana, Microfiche, Card 1: 1-9).

This article shows that there was not one single Lakota view of the ghost dance. Despite the very large literature on the Lakota ghost dance, most scholarship has proceeded on the assumption that there was "a Lakota point of view," neglecting the obvious fact that the Lakotas, like any other group of people, had differing opinions based on social, religious, political, and economic factors. Through these documents I want to demonstrate that there were many ways for the Lakotas to approach the ghost dance and that its religious message was understandable to the so-called progressive and nonprogressive Lakotas alike. That the progressive, or Christian and educated, people did not turn to the ghost dance in a unified body does not mean that they denied its potential power. The internal divisions within the Lakota people and the problems with the whites, not the ghost dance itself, determined the Lakotas' different approaches to it. These internal divisions had long historical, political, economic, and religious roots in the Lakota society. The ghost dance brought these conflicts to a new culmination point (Andersson 2008a; DeMallie 1982; Greene, 2014; Gage 2015; Ostler 2004; Warren 2015; Warren 2017). 


\section{Acknowledgements}

I want to express my thanks to Professor Raymond J. DeMallie for his generous and invaluable help over the years. Warm thanks are due also to Professors Douglas R. Parks and Robert E. Bieder as well as the rest of the American Indian Studies Research Institute staff at Indiana University. I also want to thank Dr. Justin R. Gage for generously allowing me to use some of the materials he had found and Professor Mark Van De Logt for his valuable comments. 


\section{REFERENCES CITED}

Andersson, Rani-Henrik. "Wanáği Wachípi Kin-The Ghost Dance among the Lakota Indians in 1890: A Multidimensional Interpretation.” PhD diss., Tampere: University of Tampere, 2003.

—. The Lakota Ghost Dance of 1890. Lincoln: University of Nebraska Press, 2008a.

—. "Perspectives on the Lakota Ghost Dance of 1890." In Reconfigurations of Native North America: An Anthology of New Perspectives, edited by John R. Wunder, and Kurt E. Kinbacher, 140-151. Lubbock: University of Texas Tech Press, 2008b.

Annual Report of the Commissioner of Indian Affairs 1891 (ARCIA), 52nd Congress, 1st Session, House Executive Document, No. 1, Part 5, Vol. 2, Serial 2934, Government Printing Office, Washington, DC, 1892.

Annual Report of the Secretary of War (ARSOW), 52nd Congress, 1st Session, House Executive Document, Vol. II, No. 1, Part 2, Vol. 1, Serial 2921, Government Printing Office, Washington, DC, 1892.

Bland, Thomas A. "A Brief History of the Late Military Invasion of the Home of the Sioux," Part II. Washington, D.C.: National Indian Defense Association, 1891.

Boyd, James P. Recent Indian Wars: Under the Lead of Sitting Bull and Other Chiefs; With Full Account of the Messiah Craze and Ghost Dances. Philadelphia: Publishers Union, 1891.

Chicago Tribune, November 23, 1890.

Colby L. W. "The Sioux Indian War of 1890-1891." Transactions and Proceedings of the Nebraska Historical Society, Vol. III, 144-190. Fremont: Hammond Bros., 1892.

Congressional Record: Containing the Proceedings and Debates of the Fifty-First Congress, Second Session, Vol. XXII, Part 1-2, Government Printing Office, Washington, DC, 1891.

DeMallie, Raymond J. “The Lakota Ghost Dance: An Ethnohistorical Account.” Pacific Historical Review 51:4 (1982): 385-405.

—. ed. The Sixth Grandfather: Black Elk's Teachings Given to John G. Neihardt. Lincoln: University of Nebraska Press, 1985.

—. "Lakota Belief and Ritual in the Nineteenth Century." In Sioux Indian Religion: Tradition and Innovation, edited by Raymond J. DeMallie, and Douglas R. Parks, 25-43. Norman: University of Oklahoma Press, 1987.

DeMallie, Raymond J., and Douglas R. Parks, eds. Sioux Indian Religion: Tradition and Innovation. Norman: University of Oklahoma Press, 1987. 
Fixico, Donald L. Call for Change: The Medicine Way of American Indian History, Ethos, and Reality. Lincoln: University of Nebraska Press, 2013.

Gage, Justin R. Literacy, Intertribal Visitation and the Ghost Dance, Unpublished Doctoral Thesis, University of Arkansas, 2015.

Greene, Jerome A. “The Sioux Land Commission of 1889: Prelude to Wounded Knee.” South Dakota History 1:1 (1970): 41-72.

-American Carnage, Wounded Knee. Norman: University of Oklahoma Press, 2014.

History Colorado Stephen H. Hart Library and Research Center

Lebbeus Foster Spencer Papers, (LFSP), MSS 596.

Hittman, Michael. Wovoka and the Ghost Dance. Lincoln: University of Nebraska Press, 1997.

Hoover, Herbert T. “The Sioux Agreement of 1889 and Its Aftermath.” South Dakota History, 19:1 (1989): 57-75.

Iapi Oaye, November 1890.

Indiana University, Lilly Library, Bloomington, Indiana

Walter Mason Camp Manuscript Collection (WMCC).

Indiana University, Main Library, Bloomington, Indiana

51st Congress 1st Session. United States Congress House of Representatives. House Committee on Indian Affairs. Council Held with a Delegation of Sioux Indians, April 15, 1890, Unpublished Hearing, Microfiche, Card 1.

McLaughlin, James. My Friend the Indian. Lincoln: University of Nebraska Press 1989 (orig. 1910). Marquette University Libraries, Milwaukee, Wisconsin.

Eugene Buechel Manuscript Collection (EBMC), Holy Rosary Mission, Special Collections and Archives.

Maddra, Sam. Hostiles? The Lakota Ghost Dance and Buffalo Bill's Wild West. Norman: University of Oklahoma Press 2006.

Mooney, James. The Ghost-Dance Religion and the Sioux Outbreak of 1890 (The 14th Annual Report of the Bureau of Ethnology to the Secretary of the Smithsonian Institution 1892-1893, Washington, DC, 1893). Lincoln: University of Nebraska Press, 1991.

National Archives and Records Service, General Services Administration, Washington, DC

Record Group 75, Records of the Bureau of Indian Affairs

Letters Sent to the Office of Indian Affairs by the Agents or Superintendents at the Pine Ridge Agency, 1875-1914 (LSASPR), M 1282, Vol. IX, Roll 10, 1985.

Special Case No. 188-The Ghost Dance, 1890-1898 (SC 188), M 4728-4729, Reel 12. 
Neihardt, John G. Black Elk Speaks: Being the Life Story of a Holy Man of the Oglala Sioux. Albany: State University of New York Press, 2008 (orig. 1932).

Newberry Library, Chicago, Illinois

The Edward E. Ayer Collection (EAYC), MS 3176.

New York Times, November 23, 1890.

Omaha Daily Bee, November 23, 1890.

Ostler, Jeffrey. The Plains Sioux and U.S. Colonialism from Lewis and Clark to Wounded Knee. Cambridge: Cambridge University Press, 2004.

Smith, Rex Allan. Moon of the Popping Trees: The Tragedy at Wounded Knee and the End of the Indian Wars. Lincoln: University of Nebraska Press, 1975.

University of Oklahoma Libraries and Archives, Norman, Oklahoma

Walter S. Campbell Manuscript Collection (WSCC).

US Serial Set, 51st Congress, 1st Session, Senate Executive Document, No. 51, Vol. 5, Serial 2682, Government Printing Office, Washington, DC, 1890.

Utley, Robert M. The Last Days of the Sioux Nation. New Haven: Yale University Press, 1963.

—. The Lance and the Shield: The Life and Times of Sitting Bull. New York: Ballantine Books, 1993.

Vestal, Stanley. Sitting Bull: Champion of the Sioux. Norman: University of Oklahoma Press, 1989 (orig. 1932).

Walker, James R. Lakota Belief and Ritual, edited by Raymond J. DeMallie, and Elaine A. Jahner. Lincoln: University of Nebraska Press, 1991.

Warren, Louis S. "Wage Work in the Sacred Circle: The Ghost Dance as Modern Religion." Western Historical Quarterly, XLVI: 2 (2015):141-168.

-. God's Red Son: The Ghost Dance Religion and the Making of Modern America. New York:

Basic Books 2017.

Washington Evening Star, January 1891.

Wunder, John R., and Kurt E. Kinbacher, eds. Reconfigurations of Native North America: An Anthology of New Perspectives. Lubbock: University of Texas Tech Press, 2008.

Yale University Yale Collection of Western Americana, Beinecke Rare Book and Manuscript Library

American Horse Papers (AHP), MSS S 903. 